\title{
Between the Mountain and the City - Ikkyū Sōjun and the Blurred Border of Awakening
}

\author{
Didier DAVIN
}

Ikkyū Sōjun 一休宗純 (1394-1481) is undoubtedly one of the most famous monks in Japan today. In the modern period, he is mainly known as a young boy solving apparently impossible puzzles, often in unexpected and amusing ways. However, this Ikkyū, commonly known as "Ikkyū-san," is only the final stage of an image that has drastically changed since the Middle Ages. This evolution has often been studied, ${ }^{1}$ and it is, indeed, a fascinating story leading to interesting questions about, for instance, the diffusion of Buddhism in Japanese society, the construction of idea of Zen, the relation between Zen and Japanese arts, etc.

However, even if the numerous later images of Ikkyū are a rich and interesting subject of examination, it is not to say that the monk who actually lived in the Muromachi period does not deserve our attention. On the contrary, it is because the "real" Ikkyū managed to be admired by his contemporaries that rumors about him gradually transformed into legends. The downside of this celebrity is that the multiple images of Ikkyū affects the way we perceive the "historical Ikkyū," and one must be very careful not to see the "real" Ikkyū through legends constructed after his death. Of course, as one may have already noticed, the notion of the "real" Ikkyu is itself highly problematic and deserves further analysis. However, in this article, we will simply consider the Ikkyu that we can know through the texts and other evidence that are widely thought to have been written by him, or reflect direct testimony about him. This is to say, mainly, his two

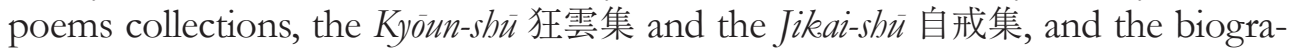
phy written by his disciples soon after his death, the Ikkyu oshō nenpu一休和尚年譜.

Among these, the Kyoun-shiu, which almost extensively records the poems Ikkyū wrote in classical Chinese during his life, is by far the most important collection for understanding him. It is not easy to read, and its interpretation is even more sensitive, as showed by the fact that a comprehensive explanation of the collec-

\footnotetext{
${ }^{1}$ Oka Masahiko 岡雅彦, Ikkeyü banashi Tonchi kōzō no raireki一休ばなし一とんち小僧の来歴. Tōkyō: Heibonsha, 1995. Iijima Takayoshi 飯島孝良, “Ikkyū no chosaku, Kyōun-shū, Jikai-shū soshite Kanahōgō”一休の著作：『狂雲集』『自戒集』そして仮名法語, Bessatsu Taiyō Ikkeyu 別冊 太陽一休, 2015, pp. 100-105.
} 
tion has yet to be published. ${ }^{2}$ Nevertheless, it constitutes the principal and almost exclusive way to access the thought of Ikkyū, and it is only by a close examination of these poems that several aspects of this intriguing monk can be observed. This paper presents one such aspects and, through it, what is certainly the most important themes of the Kyoun-shiu.

Most of the studies on the Kyoun-shū emphasize Ikkyū's image of transgression and skirting the norms of Buddhist monastic life. Indeed, many poems openly claim disrespect for - often interpreted as 'transcending' - the Buddhist precepts, and for that reason, the consumption of alcohol or sexual intercourse are often considered the main theme of the collection.

These are, undoubtedly, an important theme and should certainly not be neglected, but considering them to be the core of the Kyoun-shü in fact obscures what really motives Ikkyu and, ultimately, misleads the reader regarding the overall meaning of the collection. It is the author's position that the transgressive poems are the result of a more fundamental attitude, and, paradoxically, they can be best explained by putting them aside. However, this paper will not focus on this question and the perhaps too famous transgressive poems, but will rather consider the fundamental structure of Ikkyū's thought from one particular angle of view.

More than a taste for wine or the company of courtesans, what is perhaps most conspicuous in the Kyoun-shou is the astonishing criticism of the Zen monks of his time. No word seems strong enough when it comes to describing the villainy and the incompetence of his co-religionists, and many poems of the Kyoun-shu express one thing clearly: "I, Ikkyū, am the only one who still knows the true Zen, and all the other Zen monks are preaching a false teaching." One of the most famous stanzas of the collection summarizes this quite clearly:

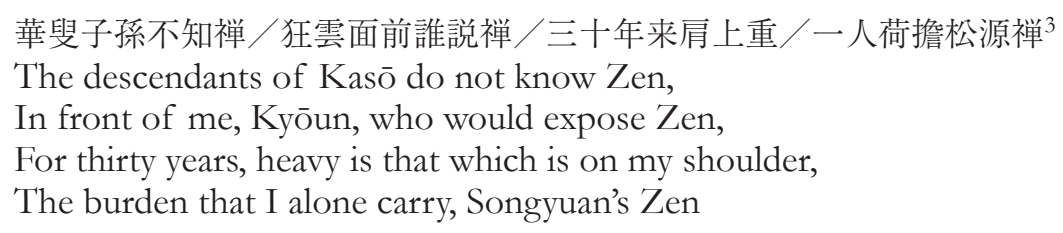

The expression "Songyuan's Zen" may look like a very restrictive part of the

\footnotetext{
${ }^{2}$ The Ikkeyü osho zenshü 一休和尚全集, (Shunjusha 1997) contains the whole of the Kyoun-shü with annotations and translation in modern Japanese, but, in spite of its undeniable value, it is unanimously recognized by specialists that the explanations provided in it are far to be enough to a complete undestanding of the collection. Several other editions, including the famous yet problematic edition by Yanagida Seizan, (Kyōun-shū 狂雲集, Chūōkōron shinsha, 2001) left many fundamental questions unresolved.

${ }^{3}$ K130. The Kyoun-shū quotes and numbering are based on Itō Toshiko 伊藤敏子, “Kyounn-shù shohon ni tsuite, fu : kōi Kyounn-shü” 狂雲集諸本について 付 : 考異狂雲集, Yamato bunka 大和文華, 1964, 41, pp. 10-59.

This stanza is written on one of the most famous portraits of the monk held at the Tokyo National Museum. (Figure 1)

https://www.tnm.jp/modules/r collection/index.php?controller=dtl\&colid=A10137
} 


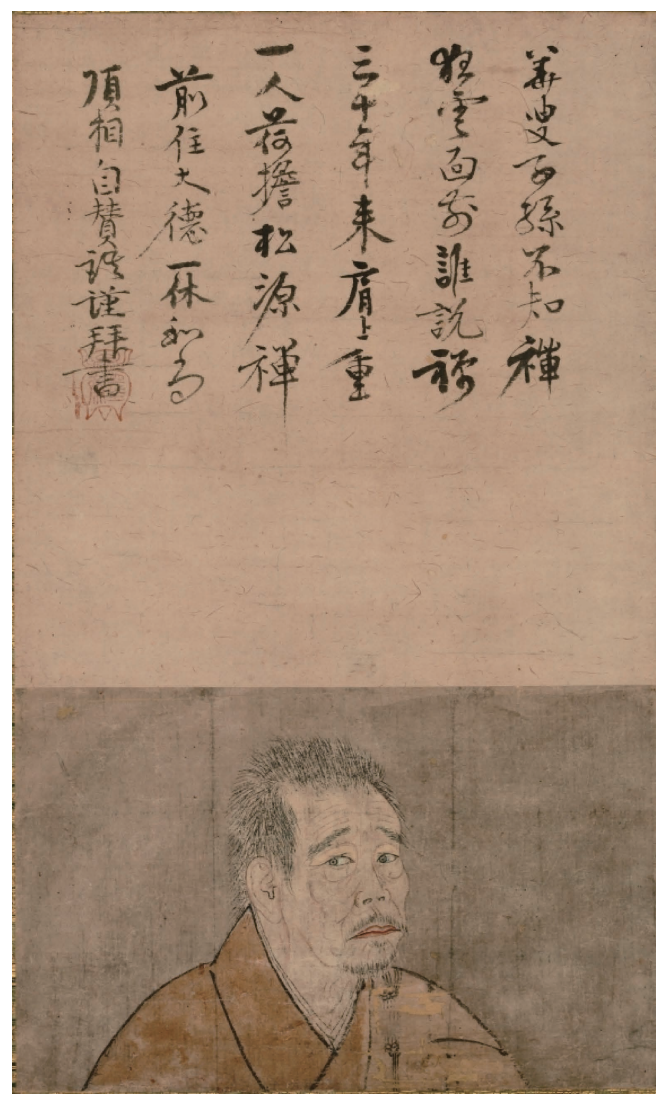

Figure 1. Portrait of Ikkyū 一休和尚像, Botsurin Jōtō 没倫紹等, Muromachi period, (Tokyo National Museum)

Zen school, but from Ikkyü's point of view, as a member of the Daitoku-ji branch - a branch that considers itself as the only remaining real Zen - referring to the descendance of Songyuan is none other than the totality of the "real" Zen. On the same principle, the "descendants of Kasō" - Ikkyū being one of them - are looked as the only legitimate part of the Daitoku-ji branch. In this way, mentioning the descendants of Kasō or the Songyuan's Zen does not describe Ikkyū as the only legitimate heir of a specific part of the Zen school, but of all the Zen teachings in the country. Suffice to say, of course, that this does not mean that Ikkyū was the only remaining Zen monk in Japan. On the contrary, during his time the Zen school was still very active and, while his golden age has passed, the so called "Gozan" (Five Mountains) institution was still an influential and powerful part of the political and religious landscape. Furthermore, the Daitoku-ji temple, which did not belong to the Gozan, ${ }^{4}$ was growing, extending

\footnotetext{
${ }^{4}$ This is a simplification. In its history, the Daitoku-ji was included in the Gozan system, but still kept a specific identity. It officially ceased to be one of the Five Mountains in 1431, during Ikkyū's life time, at the request of the abbot of the time, his fellow disciple Yōsō. For details see Tamamura Takeji 玉村竹二, “Daitoku-ji no rekishi” 大徳寺の歴史, Nihon zenshüshiron 日本禅宗史論, vol. 2-2. Kyoto: Shibunkaku, 1981, p. 311-56.
} 
broadly his influence in society. Thus, Zen monks were present in quite a number, but for Ikkyū they were not worthy to be called real monks. This severe diagnosis applied to all branches of the Rinzai school, but his criticism was aimed particularly at the closest monks, and among them his elder fellow disciple, Yōsō Sōi 養舅宗頣 (1373-1458), who inherited the “Seal of Law" from the same master as Ikkyū, Kasō Sōdon 華鼠宗量 (1352-1428). Ikkyū presents himself as the last real Zen monk, but surrounded by false monks who hold the institutional positions and, by that, the appearance of legitimacy. A very large part of the poems and stanzas collected in the Kyoun-shè can be seen as a response, or at least a reaction, to this situation.

In several compositions, the conception of Ikkyu takes the form of an opposition between two places, two realms with both a strong symbolic as well as very concrete existence: the mountain and the city. There is nothing really original in this pair of concepts, nor in the symbolism attached, but there is a specific way by which Ikkyū uses it. He seems to move along a blurry border, puzzling his reader by the unexpected path he takes between these two worlds. By following him in these compositions one should be able to see not only his views on this particular topic, but also the very core of his thought.

\section{The boring holiness of the mountain}

In the biography compiled by his disciples soon after his death, the Ikky ${ }^{\prime}$ osho nenpu (below, 'Nenpu'), the following notice can be seen. (Figure 2)

二年壬戌,

師四十九歳, 師初入讓羽山, 借民家住, 有山居偈, 後創尸陀寺徙焉, 徒侶慕 而到者, 皆爲法忘軀之流, 故拾枯掬磵, 岩路盤屈, 波々勿惓, $(\ldots)^{5}$

Second year [of Kakitsu era], jinjutsu (1442),

The master was forty-nine years old. The master entered for the first time the Yuzuriha Mountain. He lived in a rented house. There is a stanza called "Dwelling in the mountain". Later, he founded the Shida-ji temple and moved in. The disciples that came by affection to him where all of the kind who forget their own body by aspiration for the Law. For that, they gathered dead wood, draw water in the brooks tirelessly through the winding path of the mountain.

Looking only at this passage, one can see a monk leaving the turmoil of the mundane world and his disciples happily following him in a life finally fully devoted to practice. The mountain is a classical place for the retreat, Buddhist monks - among many others - often express the will to move in its protective inhospitality, and there is nothing to be surprised in the fact that, in the biography of a Zen monk,

\footnotetext{
${ }^{5}$ Imaizumi Yoshio 今泉淑夫 (ed.), Ikkeyū ōsho nenpu一休和尚年譜. Heibonsha Tōyō bunko, 1998, vol. 2, p. 285.
} 


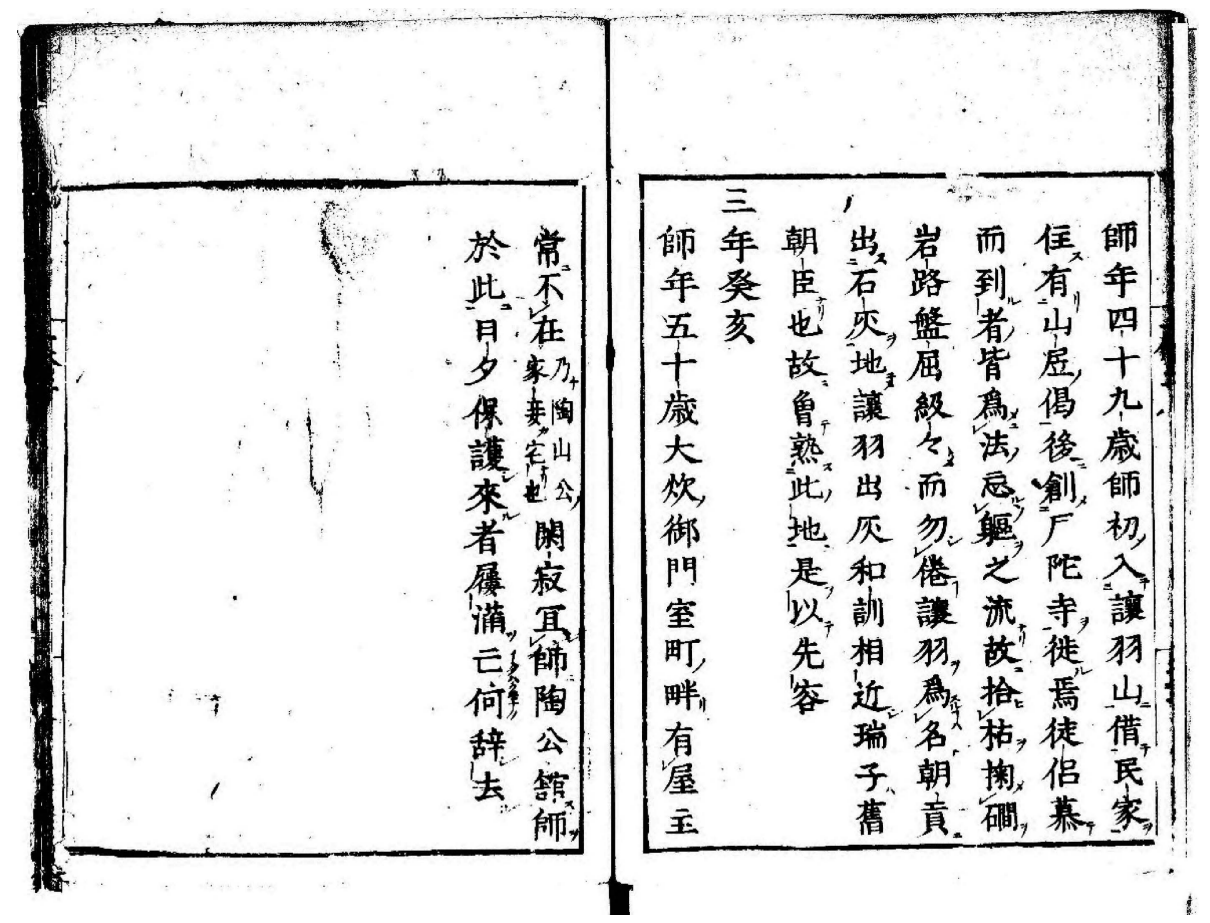

Figure 2. Ikekyū oshō nenpu一休和尚年譜, printed in 1674 (Enpō 延宝2), NIJL collection https://doi.org/10.20730/200007559

this episode is presented in a positive way. ${ }^{6}$ However, the stanza mentioned here has a quite different tone. Three stanzas are in fact entitled "Dwelling in the mountain" (Sankyo 山居) in the Kyoun-shū, two are in a pair entitled "Dwelling in the mountain, two compositions" and the third one is simply "Dwelling in the mountain". This last poem reads as follows: (Figure 3)

\footnotetext{
孤峰頂上出身途／十字街頭向背忂／空聞夜々天涯雁／郷信卦書一字無 ${ }^{7}$

The top of the solitary peak is the road to the elevation,

The crossroads in the city the way to the disparity.

In vain, every night, I listen to the wild goose in the heights of the sky,

But of a letter from home, not even a single character.
}

An examination of all the references used would exceed the scope of this article, but a few comments must be necessary to understand the general meaning of this stanza. The first two verses refer, very likely, to one of the most famous text in the Zen school, the Record of Linji, where one can read:

\footnotetext{
${ }^{6}$ The concrete motivations who pushed Ikkyū to go to the Yuzuriha mountain are unclear and an examination of the different hypothesis would be irrelevant here. See the edition of the nempu, op.cit, vol. 1, pp. 205-222 for a presentation of the various issues on the subject.

K350.
} 


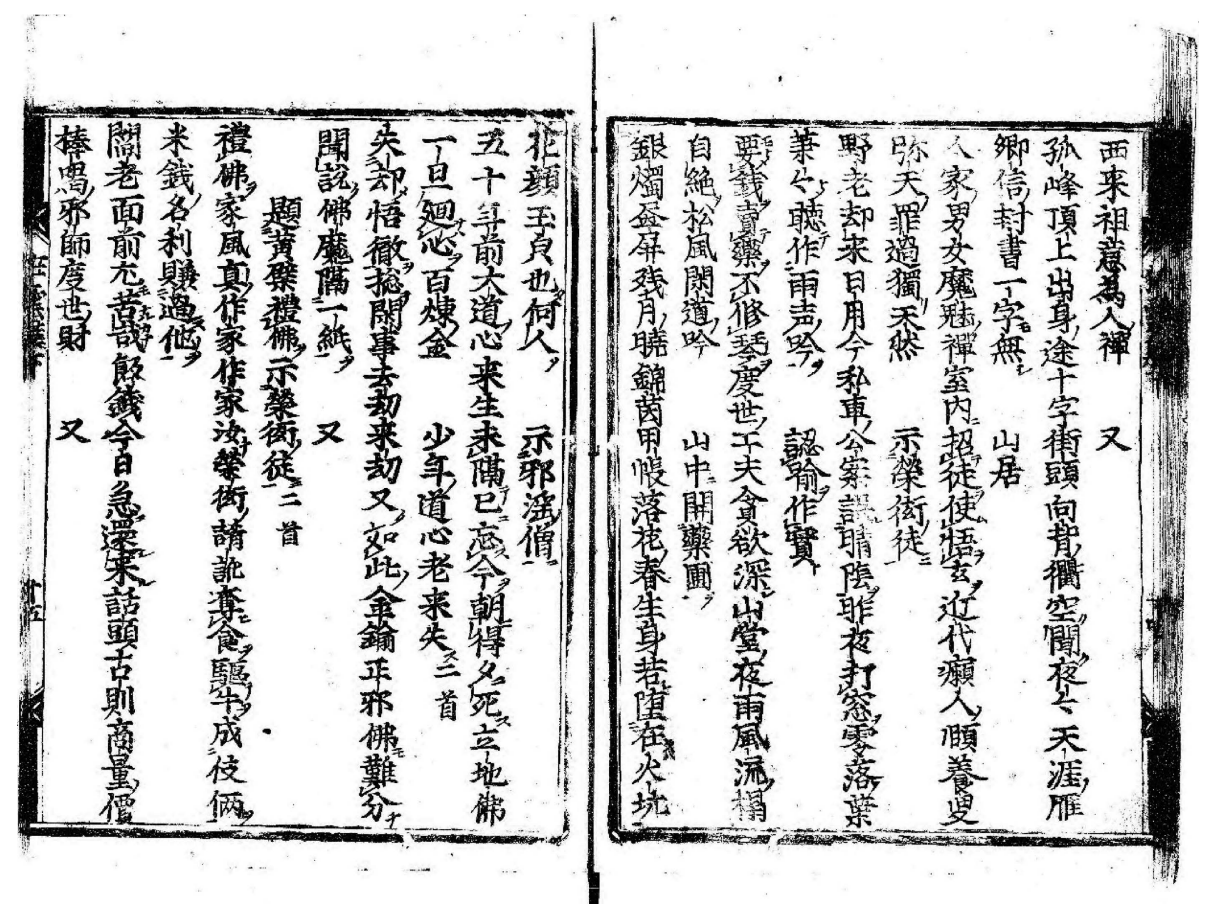

Figure 3. Kyoun-shū 狂雲集, printed in 1642 (Kan'ei 寛永19), NIJL collection https://doi.org/10.20730/200006559

上堂。云, 一人在孤峯頂上, 無出身之路。一人在十字街頭, 亦無向背。那箇 在前，那箇在後。不作維摩詰，不作傅大士。珍重。8

The master ascended to the hall and said: "One person is on top of a solitary peak and has no path to elevation. One person is at the street and the crossroads and has neither any disparity. Which is ahead, which is behind? (. . .)

The opposition between the solitary peak and the "street and the crossroad," or to say it more simply between the mountain and the city, is fundamentally the same that in Ikkyü's stanza. The mountain is the place of the elevation, shusshin (Ch. chushen 出身) a term that originally means to pass to the civil service examination, but in the specific context of Zen, refers to passing the very last stage of awakening, beyond the distinction between awakening and the mundane. At the opposite, the city is the place of the discriminative mind, where the illusionary differentiations are still made. Of course, this distinction itself, between the realm of awakening and the common world, is still a discriminative view, and must be surpassed. That is, conceivably, the purpose of Linji who describe a man in the mountain but without any way reaching to the awakening and another in the city

\footnotetext{
${ }^{8}$ Taishō shinshü dairōkeyō, vol. 45, p. 497a.
} 
who has no more disparity, that is to say who had reach the state of the awakening. Both cases are paradoxical and the question throw to the audience can be seen as an invitation to surpass this opposition.

Ikkyū, while referring to this passage, describes quite simply both the mountain and the city as the places of awakening and discrimination, and, unlike Linji, does not seem to transcend immediately this opposition. He affirms only that "The top of the solitary peak is the road to the elevation, the crossroads in the city the way to the disparity", and, by the title of the stanza the reader knows that, while saying that, he is living at the mountain, that is to say, by a superposition of the metaphor and the actual mountain, the Yuzuri Mountain, that he is, actually, in the realm of the awakening. The situation, however, does not seem to be so perfect, looking at the second half of the stanza.

The wild goose is linked with sending messages in Chinese literature since it was said that Su Wu 蘇武 (ca. 140-60 b.c.) used the leg of one of them to send a missive to the emperor. This expression is quite common and it is difficult to see a specific poem that Ikkyū refers here, but in most of the cases it implies a sadness, the missing of the beloved persons or homesick. So, in short, Ikkyū wrote, when he was in the mountain, a stanza telling, explicitly, that it is the place of awakening and, at the same time, that he is sad to be here. To understand this contradiction, or at least this tension, let us consider the pair of stanzas entitled "Dwelling in the mountain, two compositions" whose first one reads as follows:

媱坊十載興難穿／強住空山幽谷中／好境雲遮三万里／長松逆耳屋頭風9

Ten years in the brothel, the elation is not yet exhausted, I am now constrained to live in empty mountains and deep valleys.

The pleasant place is separate by clouds on thirty thousand miles,

And in the high pines, rude for my ears is the wind who passed through houses.

The first two verses are easy to understand, and the feeling express in it does not need any explanation. The brothel is, one can says, the ultimate symbol of the worldly pleasures, of the attachment at the common world and, the opposition between the mountain and the city is clearly at work here. The life in a holy place, that is, the mountain, is explicitly said to be constrained, far from the will of retreat that one can expect from a monk, or from the depiction seen in his biography. It is the city far away, that is the "pleasant place" and the sound of the wind in the pine, one of the sounds that the hermit in his retreat is expected to appreciate, remind him of the city which it passed on the way to him, in a complete inversion of the classical topos.

To summarize, in this stanza, and in the preceding stanza as well, Ikkyū describes the mountain as a holy but boring place, a place from where he regrets the forbidden pleasures of the city. One may be inclined to see in those verses the reflection of the feelings of Ikkyū and to concluded that the monk is assuming

\footnotetext{
${ }^{9} \mathrm{~K} 89$.
} 


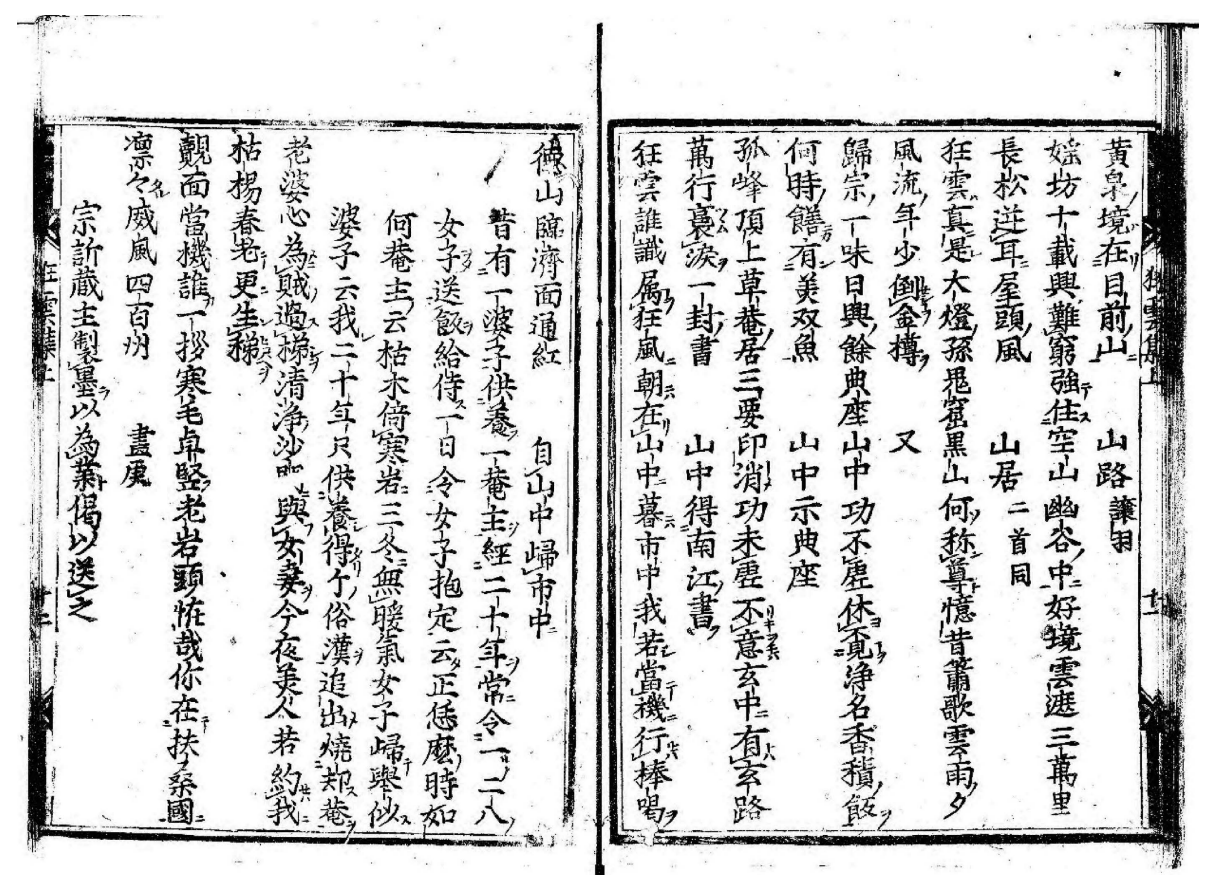

Figure 4. Kyoun-shū 狂雲集, printed in 1642 (Kan'ei 宽永19), NIJL collection https://doi.org/10.20730/200006559

openly a kind of hedonism, and indeed many commentaries are based on this understanding.

Nevertheless, it seems difficult, and a little naïve too, to look at the poems and stanza of Ikkyu as the faithful expression of what he felt. The Kyoun-shü is a collection of Chinese compositions, written in different contexts in the constraining style of the classical Chinese poetry. It is, by no mean, a diary and it would be misleading to see it as a kind of confession. Even in compositions that seems to express those impressions - maybe more than ever - one must read not what was felt by Ikkyū, but what he decided to express. This warning is particularly necessary in a poem like the following, entitled "Mountain road, Yuzuriha" (Sanro. Yuzuriba 山路 讓羽). (Figure 4)

\footnotetext{
吞声透過鬼門関 /豹虎蹤多古路間 /吟杖終無風月興 /黄泉境在目前山 ${ }^{10}$

Holding my breath, I pass the demon's gate,

On the old road, many tracks of wolves and tigers.

My poem-stick cannot raise for the wind or the moon,

The realm of the yellow spring, it is the mountain before my eyes.
}

Admittedly, one can see in those verses the frank expression of the aversion

${ }^{10} \mathrm{~K} 88$. 
toward an unfamiliar environment. The mountain, once again, is described not as the desired place of a peaceful retreat, but a scary world, compared to the yellow spring -hell -that annihilate even the desire of poetic composition, although it is very strong in the case of Ikkyū. The rejection of the mountain is, obviously, on the same line that the precedents, but that does not mean that it reflects the psychologic state of Ikkyū at one precise moment. Nobody knows what were the real feelings of the monk at the time and what we only see is what he wrote and wanted to be read. ${ }^{11}$

More than a confession which would have to say, "I have to confess that I am feeling uncomfortable in the mountain and missing the pleasures of the city," Ikkyu is voluntarily claiming his rejection of the realm of the mountain, including all of its associated symbolism. The question is of course, why would he reject the mountain? If there is a clear claim, there must be a clear message. What is Ikkyū telling us in his poetry?

The answer, evidently, must also be sought in the Kyoun-shü. The second stanza of the pair "Dwelling in the mountain, two compositions" gives a valuable key.

狂雲真是大燈孫／鬼窟黒山何称尊／憶昔簫歌雲雨夕／風流年少倒金樽 ${ }^{2}$

I, Kyōun, am truly the heir of Daitō,

In the demon's nest of the dark mountain, what could be worthy of respect.

I remember once, the melody of the flute, the clouds and the rain in the evening,

And refined youths who brought down barrels of wine.

These verses may seem surprising, or at least a little jarring at first glance. So far, we were speaking about the attractiveness or the repulsiveness of the mountain, or its corollary in the city, and Ikkyu is now talking, in a pair of stanzas also entitled "Dwelling in the Mountain," about the exclusivity of his legitimacy, what deserve, or not, to be respected and a puzzling nostalgia for bacchanals. By explaining those new elements, the purpose of the mountain theme in his compositions should be seen in a new light.

As said before, Ikkyū considers himself as the only recipient of the true teaching of the Rinzai school, and his contempt is mainly focused on his closest co-religionists. By claiming to be the only heir of Daitō, he repeats what was told many times and in many ways in the Kyoun-shiu. One example was given in the first quoted stanza where "the descendants of Kasō" or "Songyuan's Zen" refer almost to the same group, the very branch of Zen that Ikkyu himself belonged to. In this branch, those who should have preserved the only real Zen, the monks, had failed their duty and sinking into decadence. There is a very concrete consequence of the diagnosis Ikkyu made: the place where those monks are living, the temple, is no more a place of practice nor the symbol of the awakening, but

\footnotetext{
${ }^{11}$ The process of the Kyoun-shiu compilation is complex and not fully understood, but an examination of the various manuscripts shows that, very likely, it starts in the lifetime of Ikkyū.

${ }^{12} \mathrm{~K} 90$.
} 
a place of hypocrisy and depravation. This is, for example, expressed in the following stanza entitled "Suppress the object, do not suppress the man":

臨済児棌誰的伝／宗風滅却瞎駅辺／芒鞋竹杖風流友／曲椂木床名利禅 ${ }^{13}$

Among the descendants of Linji, who transmits his legacy?

His teaching extinguishes around the blind ass. ${ }^{14}$

Straw sandals and bamboo stick are friends of the refinement, ${ }^{15}$

And the predication chair is for the Zen of fame and gain.

This stanza is one of four dedicated to a very specific passage of the Record of Linji, and it should be understood in the whole context of the way Ikkyu interprets this passage. However, it will be sufficient to consider the issues in this article separately. The meaning of the first two verses does not contain any difficulty, and it is easy to recognize what is repeatedly claimed by Ikkyū: no one - except Ikkyu of course - is truly transmitting the Zen of Linji any longer. The predication chair (Jp. kyokuroku mokushō曲椂木床) is the chair where the abbot sits when he preaches, and it is, in this stanza, the symbol of the teaching given in the temple. Here, it is said to be motivated only by the greed of glory and gain, confirming the Ikkyü's discrediting of the monks of his time.

It would be an oversimplification to consider the mountain and the temple as equal in Ikkyü's perspective, but the proximity of the two should certainly not be forgotten. The devaluation of the "demon's nest of the dark mountain" expressed in the second stanza of the "Dwelling in the Mountain" pair, applies to the mountain, the place Ikkyu actually stands. However, this should also be understood in the global context of his criticism, and therefore also serves as a devaluation of the temple and the ideal preached in it. The expression "demon's nest of the dark mountain" itself is not an original creation of Ikkyū and refers to a totally dark place, where nothing can be seen, and, by extension, to the state of ignorance where man is still tied by the discriminative mind. It is used here to qualify the mountain, and express, once again, the rejection of it by Ikkyū, but of course, the literal meaning, a place where demons are living, is not far removed from this. The monks, living in the place they say to be holy - the temple or the mountains - are undoubtedly the "demons" and they deserve no respect. In this second stanza, the temple and the monks stand in the shadow of the abhorred mountain. More than the expression of the boredom or the fear of a new environment, this is more presumably the reject of the corrupted Zen school that should be read in the rejection of the mountain by Ikkyū.

\footnotetext{
${ }^{13} \mathrm{~K} 14$ 「奪境不奪人」.

${ }^{14}$ Reference to the last of Linji as recorded in the Record of Limji. On this see Yoshizawa Katsuhirō 芳澤勝弘, “Katsurō no zen,”瞎驢の禅, Bessatsu Taiyō Ikkyū, 2015, pp. 106-108.

${ }^{15}$ The expression füryu 風流 is very difficult to translate, especially in the case of Ikkyū who use it as a central concept. "Refinement" is only one of many possible translations of it. On its meaning for Ikkyū see Yoshizawa Katsuhirō 芳澤勝弘, “Fūkyō to fūryū," 風狂と風流, Bessatsu Taiyö Ikkeyü, 2015, pp. 110-112.
} 


\section{The unavoidable pleasures of the city}

If what Ikkyū rejects is less the mountain itself - whether as a place or as a symbol - than the Zen school of his time, if the company of his fellow monks was so unpleasant to him, why then, one may ask, did he not simply applying the true Zen he claims to have inherited alone and just stay away from them? Where is the necessity to claim his inclination for mundane pleasures in his critique of the corruption of the monks? Should a monk go to the brothel to be considered a true monk? Indeed, the core of the specificity of Ikkyū lies in this puzzling attitude, which manifests with several themes and, among them, as seen above, the praise of the city and of its pleasures. However, before considering the meaning of the city for Ikkyu, it is important to keep in mind that the general conception on the mountain, its opposition with the city and even the necessity to surpass this duality was a widely shared commonality of the time. One of the most evident manifestation of this is maybe to be found in the popularity of what was a very fashionable ideal of the time, being "Dwelling in the mountain within the city" (shichiu no sankyo 市中の山居). As it was pointed out by Yoshizawa Hajime, ${ }^{16}$ this idea, expressed in a famous verse of Bai Juyi 白居易 (772-846) saying that “The great hermit lives in the city, and the small hermit lives in the mountain” (大隱住朝市, 小隠入丘樊) spread widely in the society and manifested itself by a general taste for hermitages in, or very near to, cities. No need to say that the idealization of the retreat was an important aspect of the middle age Japan as it can be seen in literature or in the taste for landscapes paintings - very often mountainous - where a small hut is lost in the middle of the scene. But such a retreat is an ideal more often admired than concretely applied. Considering that, by the authority of a great Chinese poet, the real retreat should be in the city was very convenient and was used to praise samurais or monks who built "hermitages" in the city.

Furthermore, this tendency was especially convenient for the Zen monks, since most of their temples were actually in cities. Saying that being able to stay outside the world while being in the very agitation of the city is the mark of the great hermit, and that there is much less merit to do such practice in the mountain where temptations are almost nonexistent, was very welcome by the Zen school.

However, while situated in the same cultural context, the reject of the mountain by Ikkyu cannot be reduced to an adhesion to this fashionable ideal. First, to be "in the mountain within the city" implies a revalorization of the city. To be in it, in this case, does not mean being attracted by the mundane pleasures, but, on the contrary, to be strong enough to stay insensitive to various temptations. The schema is quite different with Ikkyū, and one way to understand it maybe to examine what can be see here as a subcategory of the city: the brothel. Let look

\footnotetext{
${ }^{16}$ Yoshizawa Hajime 芳澤元, Chūsei bukai hōkoku Muromachi-ki zenshū no shürokuka to bukeshakai 中世・部会報告 室町期禅宗の習俗化と武家社会, Historia ヒストリア, 2012, 235, pp. 87-111.
} 
at an example, one of the numerous "Self-Written Tributes" (Jisan 自賛) compiled in the Kyōun-shü.

八十窮僧大蕚苴 /婬坊興半尚勇巴 / 半醒半酔花前酒 / 臨済徳山何作家 ${ }^{17}$

The exhausted eighty years old monk I am is a big punk,

At half of my elation for the brothel, I add the appetite for boys. ${ }^{18}$

Half drank, half sober, the wine in front of the flowers,

Linji and Deshan, how can they be accomplished men?

The inclination for sensual pleasures is not here directly oppose with the respectable holiness of the mountain, but there is still a trace of this dualism through the mention of Linji and Deshan. The first half of the Stanza is easy to understand and Ikkyū outbid his transgression by adding his appetite for the boys to his patronization of the brothel. Needless to say, sexual interaction between boys and men were very common at the time and the scope of this "confession" is not to be understand in a modern, let alone an occidental, perspective. It is, nevertheless, a clear expression of an insatiable lust. But the second part seems more puzzling. To be "half drank, half sober," beside to be a clear reference to a poem of $\mathrm{Du} \mathrm{Mu}$ 杜牧 (803-853), ${ }^{19}$ is an attitude that must be understood through the common metaphor of the sobriety as the awakening. However, Ikkyū does not claim to be plainly sober, that is fully awakened, but he claims also to stay half drank. In other words, he is not staying only in the level of the awakening, no more than in the level of the vulgar. He stays between them, fully belonging to none of them.

The necessity to transcend the awakening, to not be stuck in it, is indeed a classic question in the Zen school - and in the Buddhism as well - but, what is the point to disqualify Linji and Deshan, who were both of course very well aware of this point and are, moreover, respected by Ikkyū as one can see in other stanzas of the Kyoun-shü. What is Ikkyū telling us by disqualifying them? How can a monk claiming to frequent a brothel, in the same stanza, declare himself superior to two of the most eminent monks of the Zen history?

The meaning of the theme of the brothel must be understood in a proper context. A famous episode gives an important key. Here is the version one can see in the Chanlin leiju 禪林類聚, a compilation of famous Zen texts:

世尊因自恣日，文殊三處過夏，來至靈山，迦葉問云，仁者今夏何處安居，文 殊云, 一月在祇園精舎, 一月在童子學堂, 一月在婬坊酒肆, 迦葉云, 何得住 此不如法處所, 遂乃白佛欲擯文殊, 佛云, 隨意, 迦葉即白桘, 絻拈槌, 乃見

\footnotetext{
${ }^{17} \mathrm{~K} 620$.

${ }^{18}$ The characters for nanshok $u$ 男色 'affection for men,' are not directly written, but strongly suggested by a play on the graphic composition of the two characters yüha 勇巴. By moving the upper part of the first at the top of the second the word nanshoku appears.

19 “Recalling former Travel” (Nien xiyou 念昔遊). Murakami Tetsumi 村上哲見 (ed.), Santaishi 三体詩, coll. “Chūgoku koten sen” 中国古典選, 29, 1978. Tokyo: Asahi shinbun-sha shuppankyoku, vol. 1, p. 178. For an English translation of it see Angus Charles Graham, Poems of the Late T'ang, Penguin Classics. 1965: Harmondsworth, p. 137.
} 
百千萬億文殊, 迦葉盡其神力, 桘不能舉, 世尊遂問, 汝擬貶那箇文殊, 迦葉 無對 20

The Venerable was present at the end of the summer retreat. Mañjuśrī had spent the summer in three places and just came back at the Vulture Peak. Mahākāśyapa asked him: "Vertuous man, where did you stay this summer?" Mañjuśrī answered: "I was a month in the Jetavana temple, a month in a school for children, and a month in brothels and taverns." Mahākāśyapa said: "How could you stay in places so against the Law?" and asked the Buddha to expel him. The Buddha said "as you wish," Mahākāśyapa then took the hammer (to call the attention of all). As soon as he took the hammer, he saw one hundred thousand trillion of Mañjuśrī and, even by using all his magical power he could not raise the hammer. The Venerable then asked him: "Which Mañjuśrī do you want to expel?” Mahākāśyapa did not answer.

This episode, which of course illustrates the necessity to surpass the opposition between the vulgar and the awakened, was well known within the Zen school and there is no doubt than an allusion to the brothel (and the tavern) would immediately be linked to this doctrinal point by an educated reader. The originality of Ikkyu is then less in the use of the brothel as a theme, than in his way to use it. By claiming so loudly his taste for the brothel, and moreover by posing it in opposition with the teaching of Linji and Deshan, he attacks not only the Zen school, but its very teaching in the same time. The figures of Linji and Deshan, when coming together, seem to have a special meaning in the Kyoun-shü. ${ }^{21}$ Because of the tangle in the references at work in the concerned compositions a convincing demonstration of this point will not be possible here, but depreciative verses like "Linji and Deshan are not accomplished men" 22 can be seen in many places of the collection. In Ikkyū's poetry - as well as in the works of many monks of the time -more than a precise reference to those two famous monks, it is used as a metonym for the teaching of Zen as a whole. So, what is Ikkyū's purpose here? A stanza may be helpful to answer that. It is entitled "Going back from the mountain to the city" (Sanchū yori shichū ni kaeru 自山中歸市中) :
狂雲誰識屬狂風／朝在山中暮市中／我若當機行棒掲／徳山臨濟面通紅 ${ }^{23}$
Who knows that the Crazy Cloud belongs only to the crazy wind?
In the morning I am in the mountain, at nightfall in the city.
If at the proper time I used of the stick or the shout,
The face of Deshan or Linji would turn red.

The general meaning of this stanza is similar to the previous one. The last two verses are, to say it without going into a detailed explanation, another claim of

\footnotetext{
${ }^{20}$ Zenrin ruiju 禅林類聚 (C. Chanlin leiju), Zenbunka kenkyū-jo. Kyoto, 1995, p. 373.

${ }^{21}$ It appears 19 times. Kyoun-shü 3, 17, 93, 106, 126, 146, 214, 312, 363, 453, 454, 468, 576, 577, 584, 607, 620, 678, 718.

${ }^{22} \mathrm{~K} 363$. 臨済徳山非作家

${ }^{23} \mathrm{~K} 93$.
} 
the superiority of Ikkyu. There is, however, in both stanzas, an important difference in the affirmation of his superiority compare to the others seen before them. Ikkyu is not saying here "I am the only one who is still in possession of the real Zen because no more real monk remains," but "I am superior even to the famous patriarchs of our school." Deshan, known for the efficiency of his teaching method that used beating, and Linji whose method often involved sudden shouting. Would it be then that Ikkyū not only prides itself to be the last real Zen monk in Japan at his time, but also to be the best that the school have ever had? Much more likely, Ikkyū considered the teaching of his own school perverted, and no longer worthy of respect. Claiming to prefer the pleasure of the city, or the brothel, is, admittedly, a way to express the actualization of the necessity to transcend the state of the awakening - to go beyond the mountain - but it is in the same time a way to distinguish himself from those who hypocritically pretend to aspiring to the holy sobriety of the mountain while in fact enjoying the very worldly benefits of their status as monks. This vision of the greedy monks can be confirmed, among many others, in a composition entitled "By a stanza on the brothel I shame the masters transmitting the law" (Inbo no ju wo motte tokuhō no chishiki wo haqukashimu 婬坊頌以辱得法知識)

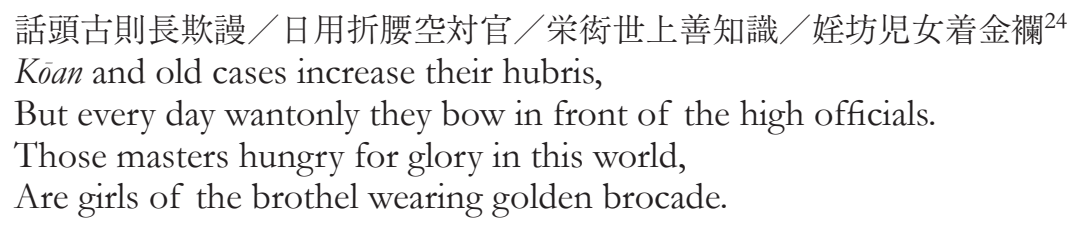

What should be underlined here is not the attack against the monks, very common in Ikkyū's work, but the one against the use of the kōan. It takes place in a specific framework that would need to be fully understand to be concretely contextualized within the evolutions of the practice in the Rinzai school of the time, but what is relevant for the present article is the verification - once again - of the fact that the monks, in their very functions, had declined. Not only the men, or the institution, but worst, the teaching itself. Even the treasured teaching of the Zen - which the practice based on the koan is the core - is no more properly done and became just a tool for the mundane elevation. For Ikkyu who presents himself as the last holder of it, the situation is hopeless.

To understand properly the meaning of the transgressive attitude of Ikkyū, one can have in mind his position against the Zen school and the desperate opinion he had about it. However, many questions remain. What did he choose to do? Why continuing to be a monk? Or, to say it in other words, where can he find a place to be after rejecting so radically the mountain? To answer those general interrogations, an examination of another question raised by the second verse of the quoted stanza must be considered. What does it mean to be the morning in the

\footnotetext{
${ }^{24} \mathrm{~K} 284$.
} 
mountain and the evening in the city? Naturally, this is not an information about the daily schedule of Ikkyū, and it is, of course, on the base of the symbolism of the mountain and the city seen before that this claim should be understood.

To be the morning in a place and the evening in another, normally unattainable, is a mark of the magic power obtained by the one who achieves Buddhahood. The expression "Going the morning in Dantaloka and arriving the evening at Luofu," 25 often seen in Zen texts, is probably the most famous example of this. Dantaloka is a mountain in India where the future Buddha is said to have practiced, and Luofu is a mountain in China. The possession of this ability, and by them the affirmation of his own awakening, is coherent with Ikkyū's discourse, but is it really only this capacity expressed here? The formulation, of course, cannot not be seen as a reference to this topos, however, why talking only about the mountain and the city? Thinking about it, there is no big mystery to be in a mountain the morning and at a city in the evening, it looks rather like the program of a pleasant Sunday hike. Quite probably, to understand properly Ikkyū's verse one can take in account the context of Ikkyū's thought. To say it roughly, what Ikkyū is telling us by claiming that he can going freely from the mountain to the city is, likely, meant to be taken at the symbolic level. That is, he can go freely from the realm of awakening to the realm of the common world. However, stopping the comprehension at this level would be considering Ikkyu in the framework of the Zen school, forgetting his strong rejection of it and the specificities it implies in it his use of Zen concepts.

For Ikkyū, to be able to go freely from a place to another is not only a mark of his freedom, but also, and paradoxically, a necessity. Because he does not resign his stature as heir of the Zen school, he cannot quit the temple, or totally renounce to the mountain, but because of the corruption of the world, he cannot fully embrace this ideal and must show his disagreement by going to city and, much more importantly, to publicizes his behavior. It is the same idea express by the expression "half drank, half sober". He is not staying only in the level of awakening, no more than in the level of the vulgar. He stays between them, fully belonging to none of them.

\section{Conclusion: Between or beyond, but never staying in}

The opposition between the holy mountain and the sinner city is not limited to Ikkyu, nor the Zen school as well, no more than is the necessity to transcend this dualism. The very hard look Ikkyū takes on his school implies a will to stay away from the other monks, or at least to express it in his poetry. To leave the mountain, or to stay drank, can be seen as a clear metaphor to say avoid the "holy" places where the monks are living. By his actions - or at least by the claim of it,

25 朝遊檀特、暮到羅浮, Koga Hidehiko and Iriya Yoshitaka, Zengo jiten 禅語辞典, 1991. Tokyo: Shibunkaku Shuppansha, p. 312. 
which is a fundamental nuance - Ikkyū locates himself - symbolically as well as physically - outside the space occupied by his co-religionists. He is seemly saying that we are not living in the same world. However, the second aspect of the paradoxical superiority repeatedly expressed by Ikkyū should be also found in his rejection of the Zen teaching itself. More precisely, it is found in his refusal of the faulty comprehension of the Zen preached by other monks. All the subtlety, and therefore the difficulty, of the position of Ikkyu resides in the fact that he rejects a teaching precisely because he values it. Praise and criticism are confusingly close in his poetry, but it is because the Zen of Linji and Deshan, the sacredness of the mountain or the aspiration to the awakening are not, per se, negated by Ikkyū. If they are criticized, and in quite violent terms, it is because the time had changed, and because of this, of the decadence of the Zen school, those highly valuable ideals are no longer appropriated. The necessity to transcend the awakening, present in the doctrines of the Zen, must be transcended again. The Zen doctrine is two-fold with the specific view Ikkyū has on his school. Ikkyū stands between two worlds, claiming to desire one - the city - to defend the true meaning of the other - the mountain. ${ }^{26}$

\footnotetext{
${ }^{26}$ The author wants to thanks Tom Newhall for his kind proofreading on this paper.
} 